\title{
Spending on Health Care in the Netherlands: Not Going So Dutch*
}

\author{
PIETER BAKX, $\dagger$ OWEN O’DONNELL $\ddagger$ and \\ EDDY VAN DOORSLAER $\S$
}

$\dagger$ Institute of Health Policy \& Management (iBMG), Erasmus University Rotterdam (EUR)

(bakx@bmg.eur.nl)

$\ddagger$ Erasmus School of Economics (ESE), EUR; Tinbergen Institute (TI), Rotterdam; University of Macedonia, Thessaloniki

(odonnell@ese.eur.nl)

$\S$ iBMG; ESE; TI

(vandoorslaer@ese.eur.nl)

\begin{abstract}
The Netherlands is among the top spenders on health in the OECD. We document the life-cycle profile, concentration and persistence of this expenditure using claims data covering both curative and long-term care expenses for the full Dutch population. Spending on health care is strongly concentrated: the 1 per cent of individuals with the highest levels of expenditure account for one-quarter of the aggregate in any one year. Averaged over three years, the top 1 per cent still account for more than a fifth of the total, indicating a very high degree of persistence in the largest expenses. Spending on longterm care, which amounts to one-third of all expenditure on health care, is even more concentrated: the top 1 per cent account for more than half of total spending on this type of care. Average expenditure rises steeply with age

\footnotetext{
* Submitted August 2015.

The authors thank two referees and Eric French for helpful comments on a previous version. Some of the results presented in this paper are based on calculations by Erasmus University Rotterdam using non-public micro data from Statistics Netherlands. The authors acknowledge support through the Netspar grant on 'Optimal Saving and Insurance for Old Age: The Role of Public Long-Term Care Insurance'.

Keywords: health expenditure, long-term care, social insurance, the Netherlands.

JEL classification numbers: D12, I13, I14.
} 
and even more so with proximity to death. Spending on individuals in their last year of life absorbs one-tenth of aggregate health care expenditure. In a given year, spending on health care is highly skewed toward individuals with lower incomes. Average expenditure on the poorest fifth is more than three times that on the richest fifth.

\section{Policy points}

- In any given year, health spending in the Netherlands is highly skewed towards poorer individuals. Those in the bottom of the income distribution spend two to three times what those at the top spend, at all stages of the life cycle.

- Health expenditures rising steeply with age and proximity to death imply substantial intrapersonal redistribution across the life cycle. Nevertheless, health care spending in the last year of life only accounts for 4.4 per cent of total medical spending (excluding long-term care) and 5.6 per cent of total health care spending (including long-term care).

- Spending on health care is highly concentrated on a small share of the population and is strongly persistent over time.

- Public spending on long-term care is high and is even more concentrated and persistent.

- The high concentration and persistence imply substantial interpersonal redistribution.

\section{Introduction}

The Netherlands is among the top spenders on health across the world and, since 2008, health expenditure has risen more steeply than in almost any other high-income country. ${ }^{1}$ There is universal coverage not only of medical care expenses but also of long-term care costs, with both financed from compulsory income-related contributions. Inconsistent with the fabled Dutch practice of each picking up his own tab, the bill for health care is largely split according to ability to pay. High and growing medical and long-term care expenditures may strain the solidarity that underpins this social insurance system. ${ }^{2}$ We document the extent to which spending on medical and long-term care is concentrated on the highest-cost patients and examine how spending is distributed in relation to income using claims data for the full population for the period 2009-11. Further, we examine the persistence of individual expenditures from year to year in order to assess the extent to which public financing is insuring against

${ }^{2}$ SER, 2012. 
fluctuating health expenses, as opposed to redistributing towards individuals with consistently high expenses.

There are three main reasons why the distribution of health care expenditures in the Netherlands may be of interest from an international perspective. First, the country combines universal compulsory coverage with competition between private providers of insurance, as well as private provision of medical and long-term care services. It is interesting to consider the distribution of publicly-financed health care achieved under such a mixed system in the context of developments both in the US, where universal insurance offered through a regulated market is beginning to operate alongside private provision of care, and in tax-financed national health systems, such as that in the UK, that are responding to funding pressures by experimenting with private provision.

Second, the Netherlands is peculiar in mandating very comprehensive universal coverage of long-term care costs. This may impact not only on the level of health expenditure (spending on long-term care is particularly high), but also on its distribution. Long-term care expenditures are likely to be concentrated on the oldest old and to strongly affect the concentration of total health spending. While ageing electorates are likely to press for increased public financing of long-term care costs, ageing of the population raises concerns about the economic viability of doing so. In this context, we examine the contribution that long-term care expenditures make to the concentration and persistence of total health spending.

Third, our analysis is based on data on personal health expenditures recorded in insurance claims for the full population. The comprehensiveness and accuracy of these data set them above what is available in most countries, facilitating analyses that would otherwise be infeasible. We can break the data down into different types of care, examine the correlation in expenditures for the same individuals over a number of years and link the data with tax records to obtain a highly accurate picture of how health spending is distributed in relation to income.

No previous study has documented the concentration and persistence of medical and long-term care expenditures for the whole Dutch population. The age profile of medical spending in a single year has been described in Vektis (2011) and lifetime medical expenditures have been simulated from claims data for two-thirds of the population by Wong et al. (2016). The latter study claims that lifetime expenditures are much less concentrated than are those for any one year, implying that cross-sectional analysis grossly overstates the interpersonal redistribution effected by public health insurance. Inequality in the distribution of health expenditures is reduced - to a substantial degree according to the simulations - when the time horizon is stretched. We do not attempt to estimate lifetime expenditures but we do examine the persistence in expenditures over a three-year period using data that are both more recent 
and more comprehensive with respect to population coverage and health care expenses included. ${ }^{3}$ In addition, we examine the distribution of health spending by income.

Claims data for 13 per cent of the Dutch population in 1999 have been used to estimate that 10 per cent of total health spending is concentrated in the last year of life. ${ }^{4}$ We update this estimate using more recent and comprehensive data, and extend the analysis to expenses incurred in the last three years of life. Analyses of the distribution of health spending in the Netherlands by disease have revealed that mental disorders are the most expensive group, accounting for more than a fifth of total expenditures on health and welfare. ${ }^{5}$ There is evidence that the utilisation of health services in the Netherlands is higher among those with lower incomes, ${ }^{6}$ but this seems to be entirely attributable to the income gradient in the burden of disease and disability. ${ }^{7}$

This paper contributes by documenting the concentration and persistence of not only medical expenses but also long-term care expenditures in the Netherlands. Only one study has previously used claims data to examine longterm care expenditures for the entire population and that study focused on the association of these expenditures with age and proximity to death. ${ }^{8}$ We are the first to examine the distribution of medical spending after a major reform in 2006 that radically altered health financing by bringing the richest third of the population, who could previously opt for private health insurance, into the social health insurance system that collects contributions in relation to income and delivers a regulated benefit package. This reform increased risk pooling and the potential for interpersonal redistribution. Establishing the effectiveness of social insurance in these respects requires good evidence on the distribution of medical spending by income and its persistence over time.

We find that health expenditures are highly concentrated: one-quarter of aggregate spending in a year is on the top percentile of the distribution. The degree of concentration falls only marginally when the data are averaged over three years - the top 1 per cent still account for more than a fifth of the total. This points to a very high degree of persistence. Indeed, 60 per cent of individuals in the top quintile of the spending distribution in one year are also at the top of the distribution the following year, and 56 per cent remain there after two years. Both concentration and persistence are even greater for expenditure on long-term care. Remarkably, the 1 per cent of individuals with the highest long-term care expenditures account for more than half of total spending on

\footnotetext{
${ }^{3}$ Wong et al. (2016) use data from 1997 to 2005 that excluded the one-third of the population with the highest incomes and did not cover long-term care expenses.

${ }^{4}$ Polder, Barendregt and van Oers, 2006.

${ }^{5}$ RIVM, 2013

${ }^{6}$ Van Doorslaer et al., 2000 and 2006.

${ }^{7}$ RIVM, 2007.

${ }^{8}$ De Meijer et al., 2011.
} 
this type of care. The high concentration of health expenditure on relatively few individuals is partly driven by the strong increase in average expenditure with age. In the whole population, the top 5 per cent account for 60 per cent of aggregate spending, but this share of spending is just over 35 per cent for the elderly (those aged 65 and above). One of the reasons for the difference is that many of those at the top of the distribution are elderly. But this is not the entire story. Restricting attention to individuals between the ages of 25 and 64, the top 5 per cent in the distribution still account for 60 per cent of total expenditure. Rapidly-rising spending in the last months of life also contributes to the highly concentrated nature of health expenditure. Spending on individuals in their last year of life, who correspond to only 0.8 per cent of the population, absorbs one-tenth of aggregate health care expenditure.

There is a strong reverse income gradient in the distribution of health expenditure in a given year. On average, the poorest fifth of the population consume health care resources that are three times more valuable than those expended on the richest fifth. This is not simply attributable to higher health spending and lower incomes among the elderly. The income gradient in spending is even more pronounced among individuals aged 25-64 than it is in the other age groups. It is likely that this reflects the impact of ill health on both income and health care utilisation in this population of working-aged individuals.

The remainder of this paper is organised as follows. Section II provides institutional background on health care financing and provision in the Netherlands and documents trends in aggregate spending on health. Section III describes the data sources used. Subsequently, we describe how medical and long-term care expenditures are concentrated in the cross-section. We do this by age and by proximity to death in Section IV and by level of spending and by income in Section V. In Section VI, we examine the persistence of expenditures over time. The final section concludes.

\section{Health care and expenditure in the Netherlands}

\section{Health care system}

\section{a) Health care financing}

Health and social care are mainly financed through two social insurance schemes that are mandatory for the entire population. One of these pays for curative care, including primary care and maternity care. It began in 1941 with coverage of the poor and has been extended to cover more groups until it became compulsory for the entire population in 2006. The other programme, which was introduced in 1968, finances long-term care for the elderly, care for the disabled and institutional mental health care. Both schemes operate on the pay-as-you-go principle. 
TABLE 1

Financing of social health and long-term care insurance, 2015 budgets

\begin{tabular}{l|cc}
\hline & Health insurance & Long-term care insurance \\
\hline Earmarked contributions and premiums & $83.5 \%$ & $73.4 \%$ \\
Government subsidy & $9.6 \%$ & $17.6 \%$ \\
Cost sharing & $7.1 \%$ & $9.0 \%$ \\
\hline
\end{tabular}

Source: Zorgcijfers, 2015a.

Social health insurance for curative care is financed mainly by incomerelated contributions (47 per cent of total revenue in 2015) and a communityrated premium (36 per cent). ${ }^{9}$ The remainder comes from deductibles ( 7 per cent) and from two tax-financed government subsidies that cover care for children and home care (10 per cent) (see Table 1). There is a mandatory annual deductible of $€ 385$, with an option to raise this to $€ 885$ (2016) in return for a premium discount. ${ }^{10}$ Expenditures on primary care, maternity care, home care, medical devices and the management of chronic conditions are excluded from the deductible.

Social health insurance is organised as managed competition. Citizens choose a health plan annually from those offered by competing private nonprofit insurers. The government specifies the services and products to be covered by basic health plans. Insurers compete on the community-rated premium and the service level (see footnote 9). They select health care providers to be included in their network and negotiate with them on prices (for some procedures). Insurers may not refuse applicants. There are implicit cross-subsidies from low to high risks through the community rating, as well as explicit cross-subsidies through a risk adjustment scheme. The latter do not fully equalise the expected loss between groups and insurers are compensated for their losses on some types of care at the end of the year. ${ }^{11}$

\footnotetext{
${ }^{9}$ Contributions are levied on all income, including pensions and benefits. The rate is 6.95 per cent of earnings up to $€ 51,974$, with no additional payments on earnings above that threshold. The retired and the self-employed pay a rate of 4.85 per cent (Zorgcijfers, 2015b). Community-rated premiums vary across health plans offered by private insurers. Within a health plan, everyone pays the same premium, although a discount of up to 10 per cent may be given to members of a group, which is usually defined by a common employer. Premiums vary across health plans mainly in relation to the service level offered: the size of the provider network, how the insurance company may be contacted and how claims may be submitted (van de Ven and Schut, 2008).

${ }^{10}$ Rijksoverheid, 2016. The discount depends on the magnitude of the increase in the deductible and varies between insurers. The average discount for increasing the deductible by $€ 500$ was $€ 240$ in 2014 (van Winssen, van Kleef and van de Ven, 2015).

${ }^{11}$ Schut and van de Ven, 2011; Zorginstituut Nederland, 2015.
} 
Long-term care insurance is financed through income-related contributions (73 per cent), ${ }^{12}$ a subsidy financed from general government revenues (18 per cent) and co-payments (9 per cent) (see Table 1$).{ }^{13}$ Co-payments are related to the type and amount of care used, the recipient's income and wealth (excluding housing), and household composition. ${ }^{14}$ Long-term care insurance covers expenditures on institutional care. It also covered expenditures on home care in the past, but the financing of this care has been reformed recently: domestic help (since 2007) as well as support with activities of daily living and some personal care (since 2015) are now tax funded, while nursing and most personal home care have been covered from social health insurance since 2015.

In 2014,85 per cent of the population opted to take supplementary insurance of expenses not covered by the social health insurance scheme, such as dental care, optometry and physical therapy..$^{15}$ This supplementary insurance rarely covers more expensive treatment substitutes or pays for deductibles. Outof-pocket payments are made for care not covered through public health insurance, including certain branded off-patent prescription drugs and overthe-counter medicines. Private long-term care insurance is non-existent ${ }^{16}$ and private expenditures on long-term care other than co-payments are limited. ${ }^{17}$

\section{b) Health care provision}

Hospitals are private non-profit organisations. Market entry is regulated but there are only requirements concerning the profit status and the way in which the organisation is governed. ${ }^{18}$ All health care professionals must be registered and are employed by private non-profit organisations or are self-employed. Three-quarters of medical specialists are organised in partnerships, which are usually specific to a hospital and a specialty. ${ }^{19}$

General practitioners (GPs) receive an annual capitation. All other medics are paid on a fee-for-service basis. ${ }^{20}$ Hospitals are paid an amount specific to a Diagnosis Treatment Combination (DTC). The DTC classification is similar

\footnotetext{
${ }^{12}$ Contributions are 9.65 per cent of income up to $€ 33,589$, with no additional payments on earnings above that threshold (Zorgcijfers, 2015b).

${ }^{13}$ Zorgcijfers, 2015a.

${ }^{14} \mathrm{CAK}, 2015$.

${ }^{15}$ Vektis, 2015.

${ }^{16}$ OECD, 2011.

${ }^{17}$ Jonker et al., 2007.

${ }^{18}$ Provision of a few procedures, including proton therapy and organ transplants, is limited to a small number of accredited hospitals (Rijksoverheid, 2014; WTZI, 2015).

${ }^{19}$ Helderman et al., 2005.

${ }^{20}$ Integrated care for some groups of chronic patients that is organised by care groups has been financed through bundled payments since 2012. These bundled payments cover all care for these patients, except for inpatient care, drugs, durable medical equipment and diagnostics. Their level is negotiated between the care groups and health insurers (Tsiachristas et al., 2013).
} 
to US Diagnosis Related Groups (DRGs). DTC rates are negotiated between hospitals and insurers for some procedures, the share of which is rising over time. ${ }^{21}$ The rates for other procedures are set by the government. ${ }^{22}$ Medical specialists received a fixed payment per DTC, which is set by the government and was integrated in the DTC rate in $2015 .^{23}$

Nursing homes and other institutional long-term care providers receive a per diem rate that is set by the government and that depends on the type and amount of care the patient is assessed to need. Home care providers are paid on a fee-for-service basis and either negotiate hourly prices with the regional single payer or bid for contracts with municipalities. ${ }^{24}$ Rather than receiving in-kind home care from a formal provider, the person in need of care can opt to receive cash that must be used to either compensate an informal carer (possibly a relative) or pay a professional caregiver. ${ }^{25}$

GPs act as gatekeepers for all secondary and tertiary care financed through social health insurance. ${ }^{26}$ For care covered through social long-term care insurance, access is determined by independent assessors, with eligibility dependent upon the health status and disability of the applicant. ${ }^{27}$

\section{Trends in aggregate health expenditure}

Aggregate health spending is documented in the National Health Accounts assembled by Statistics Netherlands. ${ }^{28}$ We concentrate here on expenditure on personal health care, which excludes spending on administration. From the left-hand panel of Figure 1, it can be observed that total expenditure on personal health increased from 7.6 per cent to 9.8 per cent of GDP between 1972 and 1982, and then remained at around that proportion over the next two decades. After fiscal restraints were relaxed from 2001, the percentage of GDP that is spent on personal health care increased by a third over the next 13 years, to reach 13.3 per cent by 2013 . As a result, the Netherlands is now the country with the highest level of spending on health care in the world after the US. ${ }^{29}$ Much of the increase in spending since 2001 was the result of

\footnotetext{
${ }^{21}$ The procedures for which DTC rates were negotiated accounted for 34 per cent of total hospital expenditures in 2009-11, rising to 70 per cent from 2012. Total expenditure on these procedures was capped at the hospital (and aggregate) level until 2012 and since then has been capped at the aggregate level (Schut and Varkevisser, 2013).

${ }^{22}$ Schut and Varkevisser, 2013.

${ }^{23}$ Oostenbrink and Rutten, 2006; Schut and Varkevisser, 2013.

${ }^{24}$ Home care providers may be for-profit organisations even when revenue is solely from social long-term care insurance.

${ }^{25}$ Bakx et al., 2015.

${ }^{26}$ Helderman et al., 2005.

${ }^{27}$ Staatscourant, 2014.

${ }^{28} \mathrm{CBS}, 2016$.

${ }^{29} \mathrm{OECD}, 2015$.
} 
FIGURE 1

Personal health care expenditure
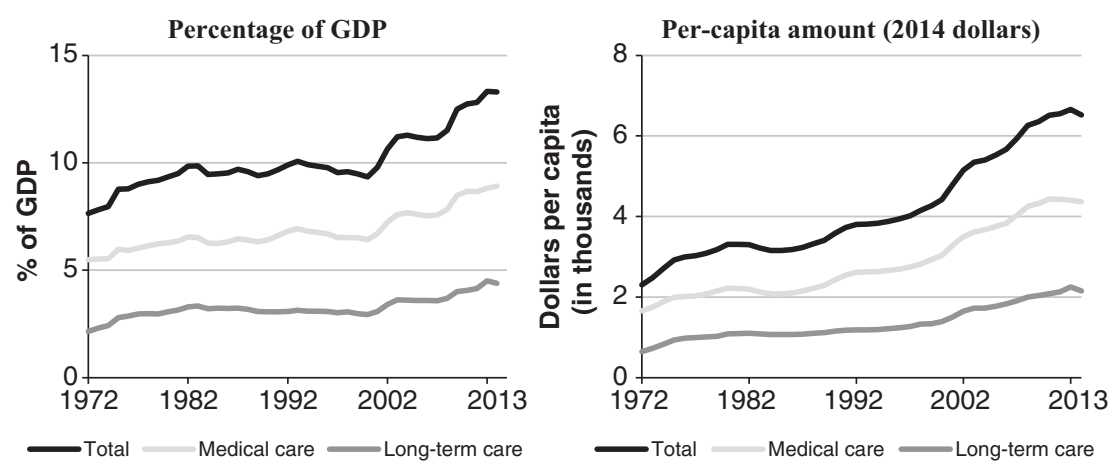

Note: Medical expenditure includes spending on hospital care, primary care, professional services, medicine, medical devices, vocational rehabilitation, prevention, supporting organisations and other medical care. Long-term care expenditure includes spending on long-term care for the elderly and care for the disabled. The definition of expenditures changed in 1998, which decreased expenditures by 0.4 per cent. Source: Authors' calculations based on CBS (2016).

a greater propensity to use hospital care, as well as the introduction of new technologies. $^{30}$

Expenditure on personal health care can be disaggregated into spending on medical care and spending on long-term care. The former includes spending on hospital care, primary care, professional services, medicines and medical devices, all of which are covered from social health insurance and are included in the claims data we analyse below. Also included in medical expenditure is spending on vocational rehabilitation, prevention, supporting organisations and other medical care. These are not financed from social insurance and are not included in the micro data analysed. Expenditure on long-term care includes spending on institutional care and home care for the elderly and the disabled, which is covered by social long-term insurance and other schemes and is included in the micro claims data.

As a percentage of GDP, expenditures on medical care and on long-term care have moved in parallel since 1972. In 2013, spending on medical care reached 8.9 per cent of GDP ( $\$ 4,368$ per person) and long-term care expenditure amounted to a very substantial 4.4 per cent of GDP ( $\$ 2,149$ per person). Expenditure on long-term care for the elderly is the highest among the OECD countries and almost 2.5 times the OECD average. ${ }^{31}$ Since 2001, per-capita expenditure on both types of care has increased by around 40 per cent in real terms (right-hand panel of Figure 1). Due to the lower level of spending on

\footnotetext{
${ }^{30}$ De Meijer et al., 2013.

${ }^{31}$ OECD, 2011.
} 
TABLE 2

Expenditure on personal health care, by type and payer

\begin{tabular}{l|rrr}
\hline & 1998 & 2006 & 2014 \\
\hline Expenditure types & & & \\
Long-term care & $33.0 \%$ & $33.5 \%$ & $34.2 \%$ \\
Hospital care & $29.8 \%$ & $29.9 \%$ & $32.5 \%$ \\
Outpatient drugs & $10.1 \%$ & $9.2 \%$ & $6.5 \%$ \\
Professional services & $17.8 \%$ & $18.3 \%$ & $17.8 \%$ \\
Other health care & $9.3 \%$ & $9.1 \%$ & $9.0 \%$ \\
Payers & & & \\
Social insurance & $69.1 \%$ & $80.1 \%$ & $81.6 \%$ \\
Private insurance & $14.5 \%$ & $4.8 \%$ & $4.3 \%$ \\
Government & $6.3 \%$ & $7.2 \%$ & $4.8 \%$ \\
Out-of-pocket & $7.5 \%$ & $5.6 \%$ & $1.7 \%$ \\
Other & $2.5 \%$ & $2.3 \%$ & \\
Total personal health care & & & 106.2 \\
Expenditure in billions (2014 dollars) & 62.1 & 90.0 & \\
\hline
\end{tabular}

Note: Professional services include GP care, dental care, paramedical care and mental health care. Other health care includes medical devices, medical transportation, expenditures abroad, and other medical and long-term care. 'Social insurance' refers to expenditures paid for by compulsory insurance. 'Government' refers to expenditures that the government pays for directly. Out-of-pocket payments do not include payments that count toward the public health insurance deductible. 'Other' payer refers to payments made by corporations, international organisations and foreigners.

Source: Authors' calculations based on CBS (2016).

long-term care, the difference in the absolute amounts of expenditure on the two categories has widened.

Table 2 shows the fractions of spending on personal health care by the type of expenditure and the source of finance. In 2014, around one-third of total personal health spending was on long-term care and this fraction has remained roughly constant since 1998. Another near third of spending is on hospital care, with this fraction having increased by 3 percentage points since 1998. This share is comparable to those in the US, France and Switzerland. ${ }^{32}$ Spending on professional services - payments to GPs, dentists, paramedics and mental health professionals - accounts for 17.8 per cent of the total. The decrease in the share of spending on outpatient prescription drugs, which in 2014 is only 6.5 per cent of the total, is the result of generic substitution and of financing some expensive outpatient drugs through hospital budgets.

The mix of health financing has changed more markedly in the period 1998-2014 than has the distribution of spending across types of care, as shown in Table 2. Between 1998 and 2006, the share of expenditure paid through

\footnotetext{
${ }^{32}$ OECD, 2015.
} 
public health insurance increased to reach four-fifths of the total, pushing the contribution of private insurance to only one-twentieth. This is the result of the 2006 reform that made public health insurance mandatory for the entire population and not only for the two-thirds with the lowest incomes. The share of government financing has increased to reach 7.8 per cent, partly as a result of transferring financial responsibility for domestic help from public long-term care insurance to municipalities. Reliance on out-of-pocket (OOP) payments has fallen markedly and they contributed only one-twentieth of total health financing in 2014. This is the lowest proportion among OECD countries, ${ }^{33}$ although payments that are part of the social insurance deductible are not included. Private financing through OOP payments and insurance combined contributed less than one-tenth of the total.

\section{Data}

We analyse the concentration and persistence of personal health care expenditures using individual-level data for the full population in the period 2009-11. Data on medical care expenditures are obtained from claims that are approved and paid by insurers operating within the mandatory social health insurance system. These data, which are collated and administered by a private agency (Vektis), cover the entire population of individuals who are required to hold public health insurance. ${ }^{34}$ This excludes only the military, foreign students below the age of 30 and individuals who have a moral objection usually founded on religious beliefs - to the purchase of health insurance. Expenses paid by the patient in the form of a deductible are recorded in the claims data. The data include expenditures on all services covered by public health insurance: GP care, maternity care, hospital treatment, specialist care, rehabilitation, pharmaceuticals, short-term mental health care, medical devices and medical transport. For children (under 18 years old), expenditures on physical therapy and dental care are also recorded.

Excluded are expenditures on services that are not covered by social insurance. Hence, the cost of any medical treatment financed from supplementary private insurance is not included. While 85 per cent of the population have this cover, ${ }^{35}$ it financed only 4 per cent of total personal health care expenditure in 2014 (see Table 2). Supplementary private insurance mainly covers dental care and physical therapy, which are likely to be lowercost treatments. Consequently, it is likely that we are missing expenditures toward the bottom of the distribution and will slightly overestimate the extent to which expenditures are concentrated at the top. Also missing are OOP

\footnotetext{
${ }^{33}$ OECD, 2015.

${ }^{34}$ Five per cent of the population are covered through a proxy holder and are excluded from the data set. The data are weighted to allow for this omission and ensure population representativeness.

${ }^{35}$ Vektis, 2015.
} 
payments other than those that count toward the public insurance deductible. Again, it is likely that this results in some exaggeration of the degree to which individuals with particularly high levels of expenditure account for a large share of the total amount spent on medical care.

Data on long-term care are obtained from the Central Administration Office of the long-term care insurance scheme (CAK). The data include the use of - and expenditures on - institutional care and home care. Care provided to children (under 18 years old) is not recorded, and there is no reliable estimate of total spending on long-term care for minors. Cash benefits paid in compensation for informal care, which account for 9 per cent of total social long-term care expenditures in $2013,{ }^{36}$ are not recorded in these data.

For institutional care, the data record the units (days) of utilisation received by an individual over a year. The corresponding tariff paid to the provider and set by the government depends only on the type and amount of care for which the person is eligible. For most episodes, this tariff can be determined from the information provided in the data. ${ }^{37}$ We multiply units of utilisation by the tariffs to get annual expenditure on institutional care for each individual. The data record the number of hours of home care of a particular type-for example, nursing - received by each individual each month but not the negotiated price. In the absence of individual-specific price data, we multiply the hours of care received by each individual by an average price for that type of care. ${ }^{38}$

The two expenditure data sets are linked at the individual level by Statistics Netherlands using a unique identification number recorded on all administrative records. This number is issued to all citizens upon mandatory registration with the municipality of residence, usually at birth or at the time of immigration. In order to describe the distribution of personal health care expenditures by income, we make use of the link of the two expenditure data sets to the tax records for the full population..$^{39}$ The measure of income adopted is gross household income equivalised to take account of household size and structure. ${ }^{40}$ In order to calculate expenditures by age and proximity to death,

\footnotetext{
${ }^{36} \mathrm{CBS}, 2016$.

${ }^{37}$ For individuals for whom the type and amount of care have not been specified, we use the tariff from the previous or next episode of care. If there is a single episode for which no tariff is available, then we use the average tariff over the population using institutional care.

${ }^{38}$ For care covered through the social long-term care insurance scheme, utilisation is registered by type of care (nursing, personal care, and support) whereas prices are set per sub-type of care (for example, basic, extra and special for nursing care) (NZA, 2009, 2010 and 2011). We calculate a year-specific price per type of care as a (volume-) weighted average of the respective sub-types (CBS, 2015). For domestic care covered through the Social Support Act, prices differ between municipalities. We calculate the (population-) weighted median price per year. Any bias from taking averages is likely to be small because the price differences are limited and the share of the population that uses long-term care is small.

${ }^{39}$ Income information is not available for 5 per cent of the population. These individuals are included in all analyses except, obviously, for that of expenditure by income.

${ }^{40}$ Equivalised household income $=$ Gross household income $/(\text { No. of adults }+0.7 \times \text { No. of children })^{0.7}$ (Citro and Michael, 1995).
} 
the expenditure and income data are linked with data on gender, date of birth and date of death taken from the Municipal Registry. Statistics Netherlands provided one of us (Bakx) with remote fingerprint-protected access to a secure server holding the individual-level linked administrative data.

To facilitate comparison with analyses for other countries presented in this issue, all monetary amounts have been converted to 2014 prices using the Dutch Consumer Price Index for $2009-14^{41}$ and to US dollars using the average exchange rate in $2014 .{ }^{42}$

\section{Health expenditure over the life cycle}

\section{Average expenditure by age}

Before examining the concentration of health expenditures - the extent to which relatively few high-cost patients account for a large share of total spending and the persistence of expenditures - the extent to which a high-cost patient in one year also incurs high costs in the next - it is worth making clear how strongly expenditures are correlated with age. The concentration of spending is, to some extent, a concentration on the old and serial correlation will partly be driven by persistently high spending in old age. Figure 2 shows per-capita annual expenditure on personal health care by age and gender. The increase

\section{FIGURE 2}

Average annual expenditures on personal health care per person, by age, gender and type of expenditure, 2009-11 (US\$2014 prices)

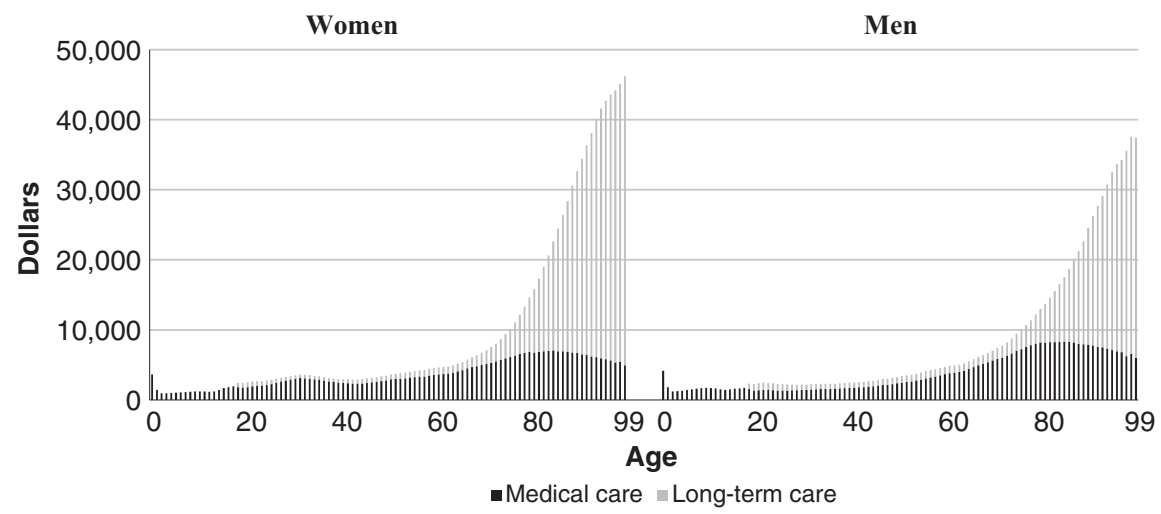

Note: Calculated from Vektis and CAK data pooled across years 2009, 2010 and 2011. Number of observations is $47,309,246$. Medical expenditure is all spending on personal health care excluding that on long-term care. Long-term care expenditures are not recorded for ages 0-17.

\footnotetext{
${ }^{41} \mathrm{CBS}, 2016$.

${ }^{42}$ Eurostat, 2015.
} 
FIGURE 3

Percentages of total personal health care expenditure and of population, by age, 2009-11

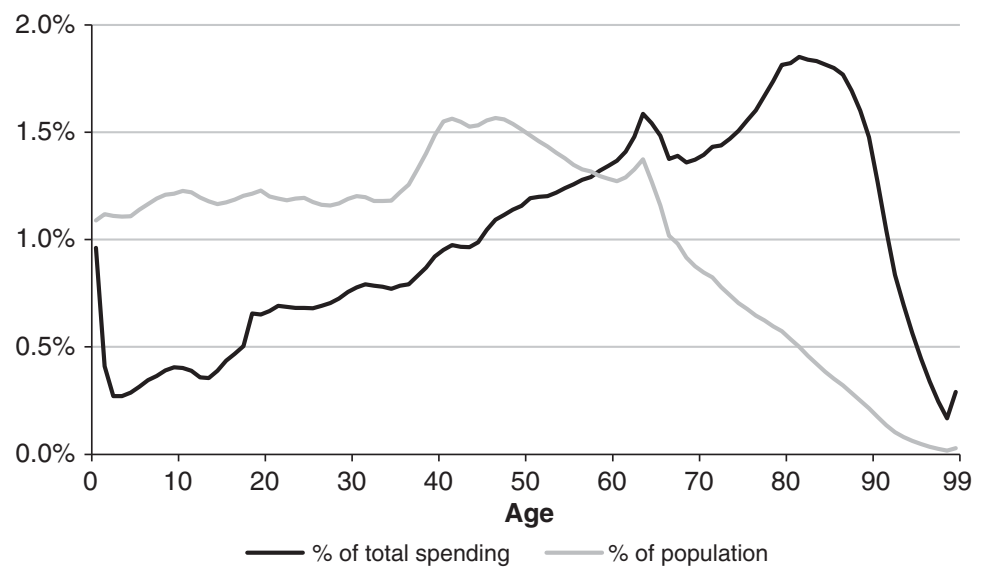

Note: Calculated from Vektis and CAK data pooled across years 2009, 2010 and 2011. Number of observations is $47,309,246$. Health expenditure is all spending on medical care and long-term care for ages 18-99 and spending on medical care for ages $0-17$.

in spending above the age of 70 is staggering. On average, $\$ 42,729$ is spent on women aged 95 . This is almost eight times the $\$ 5,439$ spent on the average woman aged 65. Average spending on a 95-year-old male is almost six times the average amount spent on a 65-year-old male. The highest-cost cases tend to be very old and so these individuals will account disproportionately for the concentration of total spending at the top of the distribution.

Of course, the share of the population at very old ages is small and so spending on these groups does not necessarily account for a large fraction of total health expenditure. As is evident from Figure 3, after infanthood, the share of total health expenditure spent on single-year age groups generally rises, and differs from the respective population share, until the age of 82 . The peak in the spending share at ages $62-65$ is due to the increased population share of this post-Second-World-War baby-boom cohort. Every single-year age group between the ages of 74 and 88 consumes at least 1.5 per cent of total health expenditure, and none has a population share of more than 0.7 per cent. From the age of 90 , the share of spending falls rapidly despite the continued rise in spending per capita because of the very steep decline in the population share of the oldest old. Individuals aged 95 and above account for 1.5 per cent of total spending on personal health care, which is vastly disproportionate to the population share of this group -0.2 per cent.

The steep rise in average expenditure in old age is primarily driven by spending on long-term care (see Figure 2). From the age of 79 (84), average 


\section{FIGURE 4}

Average annual medical care expenditure per person, by age, gender and type of expenditure, 2009-11 (US\$ 2014 prices)

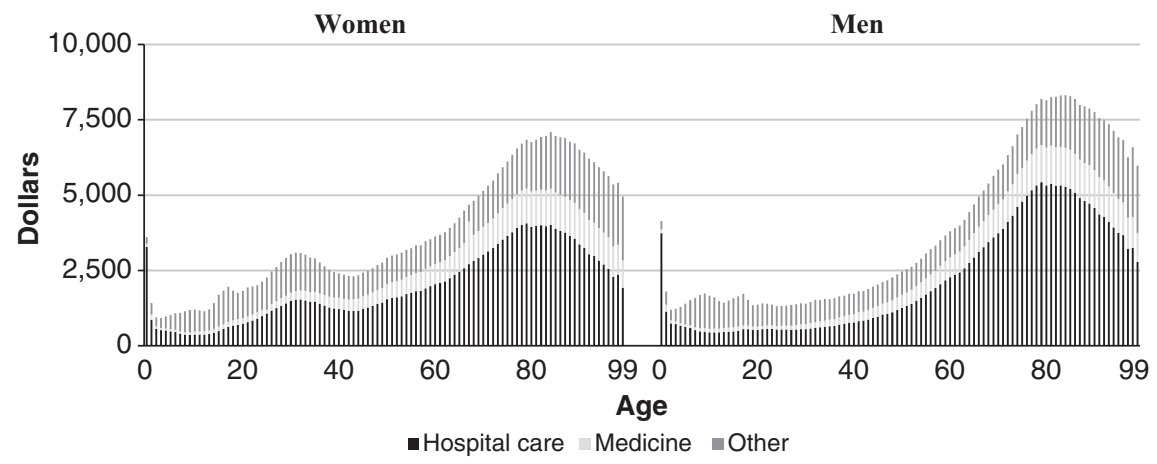

Note: Calculated from Vektis data pooled across years 2009, 2010 and 2011. Number of observations is $47,309,246$. Hospital care expenditure includes expenditures on inpatient and outpatient care and medicine that is prescribed and administered at the hospital. Medicine expenditure is for outpatient prescription medicine.

long-term care expenditures on women (men) exceed average medical care expenditures. For the oldest age group (95 and over), annual spending on longterm care reaches $\$ 38,631$ for the average woman and $\$ 28,479$ for the average man. These amounts are more than seven times and four times greater than the respective expenditures on medical care. By far the greatest part of the health care costs of the oldest old arises from long-term care needs. Long-term care expenditures are considerably higher for the oldest women than for the oldest men, possibly because women are more likely both to provide informal care while their spouse is alive and to survive their spouse. ${ }^{43}$

The very large long-term care expenses in old age make it difficult to observe the age profile of spending on medical care in Figure 2. In Figure 4, we show average spending on medical care by age and gender with a distinction between spending on hospital care and other types of care. The former includes both inpatient and outpatient care, as well as pharmaceuticals that are issued or prescribed from a hospital. The age profile of medical costs displays a pattern observed in many high-income countries. Costs are high in infanthood before falling in childhood and adolescence. For females, there is a peak at 25-40 due to motherhood. For both genders, costs rise steadily through middle age and peak at 84 . At this point, average medical spending reaches $\$ 7,086$ for females and $\$ 8,321$ for males, which are 2.3 and 3.0 times the respective average over all age groups. More is spent on females than on males between the ages of 15

\footnotetext{
${ }^{43}$ De Meijer et al., 2011.
} 
and 58. This is reversed in old age, possibly due to the higher male mortality rate. The decline in mean medical spending at the oldest ages is likely to reflect both selective mortality - those surviving into very old age are healthier - and less intensive treatment of a given condition at very old ages. ${ }^{44}$

The fraction of medical expenditures that are incurred for hospital treatment is highest for newborns (90 per cent). It rises again from middle age into old age and peaks at 60 per cent at the age of 78 for females and at 66 per cent at the age of 79 for males.

\section{Health expenditure at the end of life}

Average health spending on the elderly is high partly because of the positive correlations between proximity to death and both age and health expenditure. Table 3 shows that average expenditure in the calendar year of death is $\$ 30,659$ - seven times average expenditure across the population. These end-of-life expenditures are split roughly evenly between spending on medical care and spending on long-term care. The 0.82 per cent of individuals who die in a calendar year account for 5.6 per cent of total health expenditures in that year. Over the last three calendar years of life (i.e. 2009-11 for those who died in 2011), health expenditure reaches $\$ 99,730$ on average, and long-term care accounts for more than half of that amount.

Using the method of Hoover et al. (2002), ${ }^{45}$ average expenditure in the last 12 months of life is estimated to be $\$ 51,321$ - almost 12 times average expenditure over a 12-month period (Table 3, bottom panel). Spending on individuals in their last full year of life is 9.4 per cent of aggregate health expenditure. ${ }^{46}$ This is somewhat higher than the 6.7 per cent estimated by De Nardi et al. (this issue) for the US. The comparison suggests that the oftenheard claim that there is excessive spending on end-of-life care in the US may not be well founded. However, the estimates are not directly comparable since the US one is based on an assumption that average spending in the last year of life is the same under and over the age of 65. As is clear from comparison of the middle and right panels of Table 3 , this assumption does not hold in the Netherlands. Total expenditure in the last 12 months of life for those who die aged 65 or over is $\$ 6,665$ more than the equivalent spending for those dying

\footnotetext{
${ }^{44}$ Mackenbach et al., 2011.

${ }^{45}$ We restrict the sample to individuals who died in the observation year and regress health expenditures on (i) the number of months the individual was alive in the calendar year, (ii) the number of months alive in the calendar year squared and (iii) the square root of the number of months alive in the calendar year. The estimated coefficients are used to predict average expenditure with the number of months alive in the last calendar year set to 12 .

${ }^{46}$ This is very close to the estimate of 10 per cent produced for the Netherlands in 1998-99 by Polder, Barendregt and van Oers (2006) using data on exact spending in the last year of life for a third of the population that are extrapolated to the remainder of the population.
} 
TABLE 3

Health expenditures in the last years of life

\begin{tabular}{|c|c|c|c|c|c|c|}
\hline & \multicolumn{2}{|c|}{ All ages } & \multicolumn{2}{|c|}{ Aged under 65} & \multicolumn{2}{|c|}{ Aged 65 and over } \\
\hline & $\begin{array}{c}\text { Mean } \\
\text { (US\$ } \\
2014 \\
\text { prices) }\end{array}$ & $\begin{array}{c}\% \text { of } \\
\text { aggregate } \\
\text { annual } \\
\text { spending }\end{array}$ & $\begin{array}{c}\text { Mean } \\
\text { (US\$ } \\
2014 \\
\text { prices) }\end{array}$ & $\begin{array}{c}\% \text { of } \\
\text { aggregate } \\
\text { annual } \\
\text { spending }\end{array}$ & $\begin{array}{c}\text { Mean } \\
\text { (US\$ } \\
2014 \\
\text { prices) }\end{array}$ & $\begin{array}{c}\% \text { of } \\
\text { aggregate } \\
\text { annual } \\
\text { spending }\end{array}$ \\
\hline $\begin{array}{l}\text { Last years of life (from } \\
\text { data) }\end{array}$ & & & & & & \\
\hline Calendar year of death & & & & & & \\
\hline Total health expenditure & 30,659 & $5.6 \%$ & 28,662 & $1.7 \%$ & 31,088 & $10.2 \%$ \\
\hline Medical expenditure & 15,802 & $4.4 \%$ & 22,925 & $1.7 \%$ & 14,271 & $9.3 \%$ \\
\hline Long-term care expenditure & 14,858 & $8.0 \%$ & 5,737 & $1.7 \%$ & 16,817 & $11.0 \%$ \\
\hline Second-to-last year & & & & & & \\
\hline Total health expenditure & 39,273 & $7.4 \%$ & 30,950 & $1.9 \%$ & 41,148 & $13.7 \%$ \\
\hline Medical expenditure & 15,721 & $4.5 \%$ & 23,234 & $1.8 \%$ & 14,029 & $9.3 \%$ \\
\hline Long-term care expenditure & 23,552 & $12.9 \%$ & 7,715 & $2.2 \%$ & 27,119 & $18.0 \%$ \\
\hline Third-to-last year & & & & & & \\
\hline Total health expenditure & 29,798 & $5.6 \%$ & 20,736 & $1.2 \%$ & 31,976 & $10.6 \%$ \\
\hline Medical expenditure & 11,035 & $10.4 \%$ & 14,169 & $1.1 \%$ & 10,282 & $6.8 \%$ \\
\hline Long-term care expenditure & 18,762 & $3.2 \%$ & 6,567 & $1.9 \%$ & 21,694 & $14.4 \%$ \\
\hline Sum of last three years & & & & & & \\
\hline Total health expenditure & 99,730 & $18.6 \%$ & 80,348 & $4.8 \%$ & 104,212 & $34.5 \%$ \\
\hline Medical expenditure & 42,558 & $12.0 \%$ & 60,328 & $4.6 \%$ & 38,582 & $25.5 \%$ \\
\hline Long-term care expenditure & 57,172 & $31.3 \%$ & 20,020 & $5.8 \%$ & 65,630 & $43.4 \%$ \\
\hline $\begin{array}{l}\text { Hoover et al. (2002) method } \\
\text { Final } 12 \text { months }\end{array}$ & & & & & & \\
\hline Total health expenditure & 51,321 & $9.4 \%$ & 45,483 & $2.7 \%$ & 52,508 & $17.2 \%$ \\
\hline Medical expenditure & 24,187 & $6.7 \%$ & 35,926 & $2.7 \%$ & 21,658 & $14.2 \%$ \\
\hline Long-term care expenditure & 27,134 & $14.6 \%$ & 9,557 & $2.8 \%$ & 30,850 & $20.2 \%$ \\
\hline
\end{tabular}

Note: Calculated from Vektis and CAK data pooled across years 2009, 2010 and 2011. For mean expenditure across all ages, the number of observations is 388,026, 397,602 and 401,715 for the analyses in the calendar year of death (all deaths in 2009-11), the second-to-last year (all deaths in 2010-12) and the third-to-last year (all deaths in 2011-13), respectively. In the panel 'Sum of last three years', percentage figures give average spending on individuals in the last three years of life as a percentage of aggregate annual expenditure. For mean expenditures on decedents aged 65 and over (under 65), the number of observations is 320,422 $(67,604), 326,602(72,000)$ and 325,011 $(76,704)$ for calendar year of death, the second-to-last year and the third-to-last year, respectively.

under 65 . Because of the much higher mortality rate in the elderly population, the proportion of aggregate expenditure on this population in a calendar year that is spent on the dying is six times the fraction of total expenditure spent on those dying in the younger population. Average spending on medical care in each of the three last years of life is considerably higher in the younger 
age group. This is more than offset, however, by much higher spending on long-term care for elderly individuals close to death.

If the difference by age in end-of-life total health expenditures were the same in the US as it is in the Netherlands, then the estimate of De Nardi et al. (this issue) of the proportion of total health spending on individuals in their last year of life would be biased upward ${ }^{47}$ That would strengthen the finding that end-of-life health expenditure is not atypically high in the US, at least in comparison with a country that spends heavily on long-term care for the elderly.

Using the Hoover method, we estimate that average health spending on individuals aged 65 and over in their final 12 months before death is $\$ 52,508$ in the Netherlands. This is almost 90 per cent of the $\$ 59,100$ estimated by De Nardi et al. (this issue) for the elderly population in the US using the same method and also in 2014 prices. For both countries, health spending in the last 12 months of life is estimated to be around 17 per cent of total health expenditure on the population aged 65 and over. If there is excessive spending on seniors in the last months of life in the US, then it would appear that the same criticism could be levelled at the Dutch health system. But there is an important difference in the type of care on which resources are expended in the last year of life in the two countries. In the Netherlands, about threefifths of expenditure is on long-term care. In the US, only a quarter is on nursing home care. The Netherlands is spending much more than the US on long-term care of the elderly in their last year of life - average expenditure of $\$ 30,850$ compared with $\$ 20,900 .^{48}$ But spending on medical treatment of the elderly in the last 12 months of life in the Netherlands - \$21,658 on average - is substantially less than the respective expenditure in the US, which is slightly less than $\$ 38,200$ on average. This discrepancy suggests, without the data being of sufficient detail to confirm, that considerably more resources are expended in the US on trying to keep the dying elderly alive. In the Netherlands, which has more comprehensive coverage of long-term care, there is much greater expenditure on caring for elderly people nearing the end of life.

Figure 5 reconfirms the important contribution that spending on long-term care makes to the accumulation of health expenditure in the last year of life in the Netherlands.

\footnotetext{
${ }^{47}$ Given the difference in the composition of end-of-life expenditures in the two countries (see next paragraph), one might expect that the age gradients in these expenditures are not similar. The Dutch figures show that end-of-life medical expenditures are consistently higher in the younger population. Since relatively more is spent on medical care at the end of life in the US, this may result in higher mean end-of-life total health expenditures in the younger population in that country.

${ }^{48}$ The US estimates in this sentence and the next were kindly provided by Eric French in personal correspondence.
} 


\section{FIGURE 5}

Cumulative health expenditures in the last year of life, by months to death

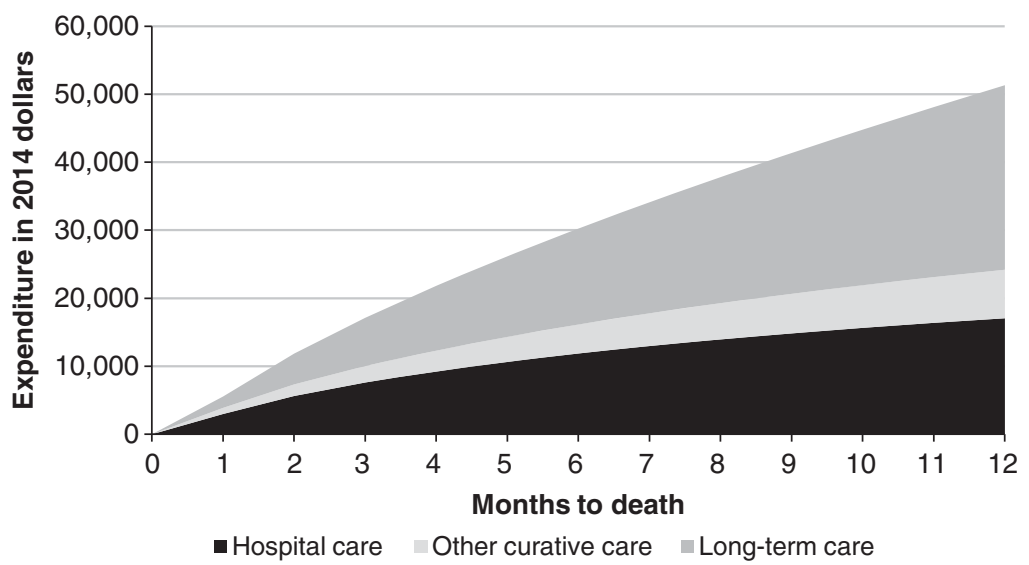

Note: Calculated from Vektis and CAK data pooled across years 2009, 2010 and 2011. Number of observations is 388,026 .

\section{Concentration of health expenditures}

\section{Cross-sectional distribution}

In a given year, most expenditure on personal health care is spent on a small fraction of the population. In Table 4, we present the distribution of annual expenditure computed from all observations pooled over the years 2009, 2010

TABLE 4

Distribution of annual health expenditures (US\$2014 prices)

\begin{tabular}{|c|c|c|c|c|c|c|}
\hline & \multicolumn{2}{|c|}{ Total health expenditure } & \multicolumn{2}{|c|}{ Medical expenditure } & \multicolumn{2}{|c|}{ Hospital expenditure } \\
\hline & $\begin{array}{l}\text { Average } \\
(\$)\end{array}$ & $\%$ of total & $\begin{array}{c}\text { Average } \\
(\$)\end{array}$ & $\%$ of total & $\begin{array}{c}\text { Average } \\
(\$)\end{array}$ & $\%$ of tota \\
\hline All & 4,398 & $100.0 \%$ & 2,894 & $100.0 \%$ & 1,552 & $100.0 \%$ \\
\hline $96-100 \%$ & 52,766 & $60.0 \%$ & 29,002 & $50.1 \%$ & 19,126 & $61.6 \%$ \\
\hline $91-95 \%$ & 12,351 & $14.0 \%$ & 8,715 & $15.1 \%$ & 4,896 & $15.8 \%$ \\
\hline $71-90 \%$ & 3,961 & $18.0 \%$ & 3,360 & $23.2 \%$ & 1,448 & $18.7 \%$ \\
\hline $51-70 \%$ & 1,112 & $5.1 \%$ & 1,059 & $7.3 \%$ & 285 & $3.7 \%$ \\
\hline $0-50 \%$ & 255 & $2.9 \%$ & 249 & $4.3 \%$ & 8 & $0.2 \%$ \\
\hline
\end{tabular}

Note: Data are annual expenditures of individuals pooled over 2009-11. Number of observations is $47,309,246$. Total health expenditure is the sum of expenditures on medical care and long-term care. Medical care in turn includes hospital care, outpatient medicine and other medical care, including professional services. Hospital care includes inpatient and outpatient care and medicine that is prescribed and administered at the hospital. 
TABLE 5

Distribution of annual total health expenditures, by age (US\$2014 prices)

\begin{tabular}{|c|c|c|c|c|c|c|}
\hline & \multicolumn{2}{|c|}{ Aged 0-24 } & \multicolumn{2}{|c|}{ Aged 25-64 } & \multicolumn{2}{|c|}{ Aged 65 and over } \\
\hline & $\begin{array}{l}\text { Average } \\
(\$)\end{array}$ & $\%$ of total & $\begin{array}{c}\text { Average } \\
\text { (\$) }\end{array}$ & $\%$ of total & $\begin{array}{l}\text { Average } \\
\text { (\$) }\end{array}$ & $\%$ of total \\
\hline All & 1,801 & $100.0 \%$ & 3,406 & $100.0 \%$ & 12,338 & $100.0 \%$ \\
\hline $96-100 \%$ & 20,594 & $57.2 \%$ & 40,229 & $59.1 \%$ & 90,028 & $36.5 \%$ \\
\hline $91-95 \%$ & 4,209 & $11.7 \%$ & 8,961 & $13.2 \%$ & 50,409 & $20.4 \%$ \\
\hline $71-90 \%$ & 1,628 & $18.1 \%$ & 3,249 & $19.1 \%$ & 18,343 & $29.7 \%$ \\
\hline $51-70 \%$ & 622 & $6.9 \%$ & 961 & $5.6 \%$ & 5,277 & $8.6 \%$ \\
\hline $0-50 \%$ & 221 & $6.2 \%$ & 210 & $3.1 \%$ & 1,184 & $4.8 \%$ \\
\hline
\end{tabular}

Note: Data are annual expenditures of individuals pooled over 2009-11. Number of observations is 13,797,871 (aged 0-24), 25,624,847 (aged 25-64) and 7,886,528 (aged 65 and over). Figures are for total personal health expenditures.

and 2011. On average, annual personal health expenditure is $\$ 4,398$ per capita. In the bottom half of the distribution, average spending is only $\$ 255$. The half of the population with the lowest levels of annual expenditure accounts for only 2.9 per cent of total expenditure. At the other extreme, average spending on the 5 per cent most expensive cases is $\$ 52,766$ and these observations account for about 60 per cent of total expenditure. ${ }^{49}$

In the middle panel of Table 4, we exclude expenditure on long-term care and examine the cross-sectional distribution of expenditure on medical care. Spending on long-term care is particularly top-heavy - only 4.3 per cent of the population make use of long-term care. Omitting these heavily-skewed expenditures results in a distribution of medical expenditure that is somewhat less concentrated at the top than that of total personal health expenditure. But the 5 per cent most expensive medical cases still account for half of aggregate medical spending. In the right-hand panel of Table 4, we restrict attention to spending on hospital treatment. Since 43 per cent of the population experience no hospital treatment in a given year, the distribution of hospital expenses is more right-skewed than is the distribution of all medical spending. Average hospital expenditure on the top twentieth of the population is $\$ 19,126$ and they account for 61.6 per cent of the aggregate of this category of expenditure.

In Table 5, we show the distribution of personal health expenditure that is specific to three age groups. This again shows that average spending is much higher on the elderly. But it also reveals differences in the distribution of expenditure by age. Among the elderly, expenditures are much less concentrated at the top of the distribution. The most expensive 5 per cent of cases in the elderly population account for 36.5 per cent of aggregate spending

\footnotetext{
${ }^{49}$ Gender-specific distributions are presented in Tables A1 and A2 in the online appendix.
} 
on this group. The respective figure for the non-elderly adult population is 59.1 per cent. $^{50}$ The lower degree of concentration of health expenditures in the elderly population is presumably due to a higher prevalence of (chronic) illness and disability that is more evenly spread across the population. Among the elderly, as for the full population, medical expenditures are more evenly distributed than total health expenditures as a result of the very unequal distribution of long-term care expenditures. ${ }^{51}$

\section{Distribution by income}

Table 6 shows the distribution of annual personal health expenditures by quintile of equivalised gross household income calculated from the crosssectional data pooled across the years 2009, 2010 and 2011. Expenditures on all personal health care are strongly negatively correlated with income. On average, the health spending on the poorest fifth of the population is $\$ 7,563$ per person per year. This is more than three times the average spending on the richest fifth. Average health spending on the poorest fifth is 43 per cent of the average income of this group. For the richest fifth, average health expenditure

TABLE 6

Average income and health expenditures, by income quintile (US\$2014 prices)

\begin{tabular}{|c|c|c|c|c|c|c|c|c|}
\hline \multirow[t]{2}{*}{ Income quintile } & \multicolumn{2}{|c|}{ Income } & \multicolumn{2}{|c|}{$\begin{array}{l}\text { Total health } \\
\text { expenditure }\end{array}$} & \multicolumn{2}{|c|}{$\begin{array}{c}\text { Medical } \\
\text { expenditure }\end{array}$} & \multicolumn{2}{|c|}{$\begin{array}{c}\text { Hospital } \\
\text { expenditure }\end{array}$} \\
\hline & $\begin{array}{c}\text { Average } \\
\text { (\$) }\end{array}$ & $\begin{array}{l}\% \text { of } \\
\text { total }\end{array}$ & $\begin{array}{l}\text { Average } \\
\text { (\$) }\end{array}$ & $\begin{array}{l}\% \text { of } \\
\text { total }\end{array}$ & $\begin{array}{c}\text { Average } \\
\text { (\$) }\end{array}$ & $\begin{array}{l}\% \text { of } \\
\text { total }\end{array}$ & $\begin{array}{l}\text { Average } \\
\text { (\$) }\end{array}$ & $\begin{array}{l}\% \text { of } \\
\text { total }\end{array}$ \\
\hline All & 47,705 & $100.0 \%$ & 4,199 & $100.0 \%$ & 2,797 & $100.0 \%$ & 1,476 & $100.0 \%$ \\
\hline Poorest & 17,526 & $7.3 \%$ & 7,563 & $36.0 \%$ & 3,666 & $26.2 \%$ & 1,798 & $24.4 \%$ \\
\hline Second poorest & 29,979 & $12.6 \%$ & 5,320 & $25.3 \%$ & 3,444 & $24.6 \%$ & 1,821 & $24.7 \%$ \\
\hline Middle & 41,281 & $17.3 \%$ & 3,239 & $15.4 \%$ & 2,579 & $18.4 \%$ & 1,388 & $18.8 \%$ \\
\hline Second richest & 55,190 & $23.1 \%$ & 2,605 & $12.4 \%$ & 2,253 & $16.1 \%$ & 1,231 & $16.7 \%$ \\
\hline Richest & 94,550 & $39.6 \%$ & 2,268 & $10.8 \%$ & 2,043 & $14.6 \%$ & 1,142 & $15.5 \%$ \\
\hline Poorest/Richest & 0.19 & & 3.33 & & 1.79 & & 1.57 & \\
\hline
\end{tabular}

Note: Income is equivalised gross household income. Data are pooled over 2009-11. Number of observations is $46,670,975$. Total health expenditure is the sum of annual expenditures on medical care and long-term care. Medical care in turn includes hospital care, outpatient medicine and other medical care, including professional services. Hospital care includes inpatient and outpatient care and medicine that is prescribed and administered at the hospital.

\footnotetext{
${ }^{50}$ The percentage of total expenditure on the top 5 per cent of the distribution is lower in each age group than it is across all age groups (compare Tables 5 and 4). This is due to the much higher level of spending on the elderly.

${ }^{51}$ See Table A3 in the online appendix.
} 
TABLE 7

Average income and personal health expenditures, by income quintile over age groups (US\$2014 prices)

\begin{tabular}{l|cc|cc|cc}
\hline Income quintile & \multicolumn{2}{|c|}{ Aged 0-24 } & \multicolumn{2}{c|}{ Aged 25-64 } & \multicolumn{2}{c}{ Aged 65 and over } \\
& Income & $\begin{array}{c}\text { Health } \\
\text { expenditure }\end{array}$ & Income & $\begin{array}{c}\text { Health } \\
\text { expenditure }\end{array}$ & Income & $\begin{array}{c}\text { Health } \\
\text { expenditure }\end{array}$ \\
\hline All & 43,049 & 1,794 & 53,511 & 3,355 & 36,510 & 11,556 \\
Poorest & 13,801 & 2,651 & 20,002 & 6,557 & 19,454 & 16,288 \\
Second poorest & 27,887 & 1,835 & 35,215 & 3,340 & 24,208 & 12,962 \\
Middle & 38,546 & 1,584 & 47,255 & 2,579 & 29,265 & 11,198 \\
Second richest & 50,539 & 1,495 & 61,712 & 2,263 & 38,464 & 9,247 \\
Richest & 84,474 & 1,408 & 103,370 & 2,035 & 71,160 & 8,086 \\
Poorest/Richest & 0.16 & 1.88 & 0.19 & 3.22 & 0.27 & 2.01 \\
\hline
\end{tabular}

Note: Income is equivalised gross household income. Data are pooled over 2009-11. Number of observations is 13,707,173 (aged 0-24), 25,404,960 (aged 25-64) and 7,558,842 (aged 65 and over). Personal health expenditure is the sum of annual expenditures on medical care and long-term care.

is only 2.4 per cent of average income. The poorest fifth receive 7.3 per cent of total gross income but get 36 per cent of all health spending.

The columns toward the right of Table 6 reveal that much of the income gradient in health expenditures is driven by the distribution of long-term care. Average expenditure on this type of care in the poorest income quintile is 17 times higher than the average in the richest quintile. ${ }^{52}$ An income gradient in the distribution of medical expenditures is evident but much less marked.

Since contributions to public health and long-term care insurance increase with earnings (up to contribution ceilings), this strong negative correlation between care purchased from social insurance and income represents a substantial redistribution from the rich to the poor in any given year. However, given that health expenditures increase steeply with age, the cross-sectional relationship between expenditures and income provides a highly misleading impression of the redistribution achieved by social insurance from a lifetime perspective.

The correlation between health expenditures and income is at most partly driven by age, as the distributions of expenditures by income quintiles specific to three age groups in Table 7 show. Within each age group, health expenditure falls steeply as income rises. Even below the age of 25 , the poorest fifth benefit from spending equal to $\$ 2,651$ on average, which is 88 per cent greater than

\footnotetext{
${ }^{52}$ There may be two explanations for this strong income gradient. First, there may be differences in the prevalence and severity of disability by income. Second, the oldest old have accumulated much lower (pension) incomes than younger cohorts, even when compared with younger retirees, and use the bulk of the long-term care. Evidence based on Dutch survey data indicates that there is no income gradient in long-term care use after controlling for disability and age (de Meijer et al., 2011; Bakx et al., 2015).
} 
that received by the richest fifth. Average health spending is 19 per cent of average income for the poorest in this age group, compared with 1.7 per cent for the richest. The income gradient in health expenditures is strongest for the working-age population. It is likely that this is largely due to the large effect that ill health has on income, through lost employment, before retirement. ${ }^{53} \mathrm{On}$ average, the poorest 20 per cent receive 3.2 times more spending than do the richest in this age group. Average health spending on the poorest fifth of the working-age population is a third of average income. For the poorest fifth of the elderly, health spending is 84 per cent of average income. It is 11 per cent even for the richest fifth of the elderly.

\section{The persistence of medical spending}

In the cross-section, health expenditures are highly concentrated on the elderly, the poor and high-cost cases. The concentration by age is consistent with social health and long-term care insurance in the Netherlands effecting substantial intrapersonal redistribution across the life cycle. The concentration by income is consistent with substantial interpersonal redistribution. The concentration of expenditures at the top of the distribution is consistent with welfare gains from single-period insurance, but only if high expenditures are not predictable. If there is substantial persistence in medical expenses, then social insurance will play more of a redistributive role. The welfare gain it generates through an insurance function will not be captured by a static single-period model but will require adoption of a lifetime perspective in which the gains from insuring the onset of chronic health conditions that persist once contracted can be evaluated. ${ }^{54}$ In this section, we examine the serial correlation in health expenditures with a view to assessing the extent to which the cross-section concentration is likely to dissipate when the analysis is stretched to a somewhat more distant horizon.

In Table 8, we show the linear correlation of individual health expenditures in levels and logs one and two years apart. ${ }^{55}$ The correlation between spending in one year and the next is high, at around 0.66 in both levels and logs. The correlation between expenditure one year and that two years later is predictably weaker but is still substantial, at 0.56 in levels and 0.61 in logs. Health spending in one year appears to be a rather good predictor of spending up to two years later. This suggests that the concentration of expenditure at the top of the distribution does not arise from single-period risks that strike randomly in

\footnotetext{
${ }^{53}$ Van Kippersluis et al., 2010; García-Gómez et al., 2013.

${ }^{54}$ Kowalski, 2015.

${ }^{55}$ Attrition is not a major issue in the estimation of these correlations. Approximately 98 per cent of the 2009 observations are observed in 2010 and 97 per cent were observed also in 2011. Mortality and migration are the main sources of attrition. Individuals observed in 2009 but not in 2010 had higher-than-average health care expenditures.
} 
TABLE 8

Correlation of health expenditures in year $t$ with expenditures in years $t+1$ and $t+2$

\begin{tabular}{l|cc|cc}
\hline & \multicolumn{2}{|c|}{ Spending in levels } & \multicolumn{2}{c}{ Spending in logs } \\
& $t+1$ & $t+2$ & $t+1$ & $t+2$ \\
\hline Total health expenditure & 0.66 & 0.56 & 0.67 & 0.61 \\
Long-term care expenditure & 0.82 & 0.70 & 0.88 & 0.79 \\
Medical expenditure & 0.43 & 0.33 & 0.60 & 0.53 \\
Hospital expenditure & 0.40 & 0.32 & 0.43 & 0.37 \\
Number of observations & $30,859,547$ & $15,128,538$ & $30,859,547$ & $15,128,538$ \\
\hline
\end{tabular}

Note: Correlations between spending in year $t$ and in year $t+1$ are calculated using pairs from the years 2009-10 and 2010-11; correlations between year $t$ and year $t+2$ are for the years 2009 and 2011. Expenditures below 10 per cent of the mean have been set to that value when calculating log expenditures.

the population. To a substantial extent, it is the same individuals who are repeatedly receiving treatment that is most costly.

Expenditures on long-term care display stronger serial correlation than do medical expenditures. This is to be expected given the chronic nature of the conditions that give rise to long-term care needs. The one-year and two-year correlations of hospital expenditures are only slightly weaker than those for all medical expenditures in levels, but they are substantially weaker in logs. The latter is what one would anticipate given that hospital expenses are more likely to be incurred for acute treatments that are not repeated, unlike the continued medication and primary care management of chronic conditions.

From the transition matrices presented in Table 9, it is apparent that the serial correlation is strongest toward the extremes of the distribution of health expenditure. Three-fifths of the individuals located in the highest quintile of expenditure in one year remain in that quintile in the subsequent year. Of those who drop out of the top quintile, more than half move to the second-highest quintile. Only 18.3 per cent fall out of the top two-fifths of the distribution of health expenditures from one year to the next. Strikingly, more than half of those in the top fifth of the distribution were still there two years later. High levels of expenditure are rather persistent, at least over a three-year period.

There is also a good deal of consistency at the bottom of the distribution. Half of those in the bottom quintile of health expenditure in one year remain there in the next. Only 4 per cent of individuals in the lowest fifth of the distribution in one year move to the highest quintile in the next, and only 6 per cent move from the bottom to the top within two years. These figures provide an indication of the rarity of health shocks that shunt an individual from the bottom to the top of the distribution of health expenditures.

The less persistence there is in health expenditures, the greater will be the reduction in concentration in their distribution when expenditures are 
TABLE 9

Transition matrices for total personal health expenditures

One-year transitions

\begin{tabular}{l|ccccr}
\hline $\begin{array}{l}\text { Quintile in } \\
\text { current year }\end{array}$ & Bottom & Second & $\begin{array}{c}\text { Quintile next year } \\
\text { Third }\end{array}$ & Fourth & Top \\
\hline Bottom & 51.3 & 23.7 & 13.1 & 7.5 & 4.4 \\
Second & 22.5 & 36.3 & 23.0 & 12.1 & 6.1 \\
Third & 12.1 & 23.5 & 33.2 & 20.9 & 10.3 \\
Fourth & 6.6 & 11.7 & 22.1 & 38.8 & 20.8 \\
Top & 3.5 & 5.5 & 9.3 & 21.5 & 60.2 \\
\hline
\end{tabular}

Two-year transitions

\begin{tabular}{l|cccrr}
\hline \multirow{2}{*}{$\begin{array}{l}\text { Quintile in } \\
\text { current year }\end{array}$} & Bottom & Second & Thintile two years ahead & Fourth & Top \\
\hline Bottom & 46.2 & 24.3 & 14.4 & 9.2 & 6.0 \\
Second & 22.4 & 33.5 & 22.8 & 13.5 & 7.8 \\
Third & 12.9 & 23.8 & 30.3 & 21.2 & 11.8 \\
Fourth & 7.5 & 13.2 & 22.0 & 35.1 & 22.2 \\
Top & 4.6 & 6.9 & 10.5 & 21.9 & 56.2 \\
\hline
\end{tabular}

Note: Cells indicate the percentage of individuals in row quintile $i$ in year $t$ who are in column quintile $j$ in year $t+1$ (top panel) or $t+2$ (bottom panel). Total personal health expenditure is all expenditure on medical care and long-term care. Number of observations is $30,859,547$ for the top panel and $15,128,538$ for the bottom one.

averaged over more years. The Lorenz curves for total health expenditures presented in Figure 6 show little evidence of this, once again confirming a high degree of persistence. ${ }^{56}$ The curve for expenditures in one year is close to a reverse L shape, reflecting the very high degree of concentration, or inequality, demonstrated in the previous section.

This is also evident from the measures of concentration presented in the top panel of Table 10. The 10 per cent most expensive cases account for threequarters of total expenditure in a year. The top 1 per cent account for a quarter. The corresponding Gini index is an astronomical $0.82 .{ }^{57}$

The Lorenz curves for two- and three-year averaged expenditures move inward, indicating less inequality, but only marginally. Over three years, the fraction of total personal health expenditure spent on the top percentile of the population is still substantially more than a fifth and the Gini index falls only five hundredths to 0.77 .

\footnotetext{
${ }^{56}$ Figure A1 in the online appendix presents the distributions in the form of cumulative density functions.

${ }^{57}$ The Gini coefficient is a measure of inequality. It is bounded between 0 and 1 , where 0 corresponds to perfect equality and 1 corresponds to maximum inequality.
} 
FIGURE 6

Lorenz curves for health expenditures for one, two and three years of expenditures

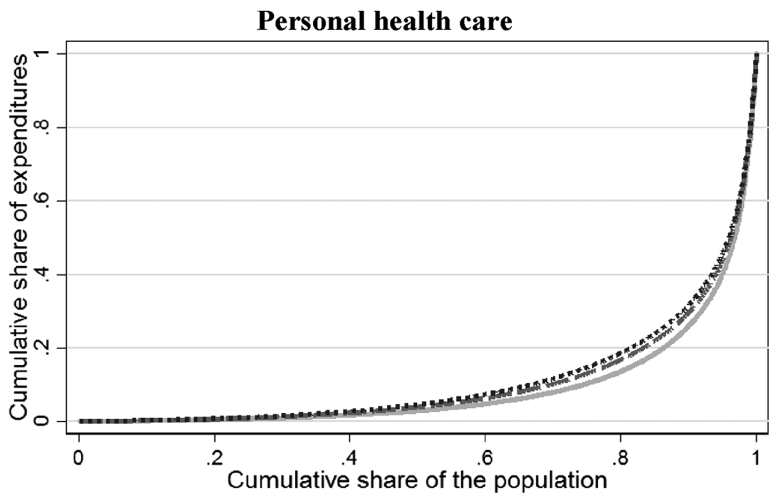

Medical care

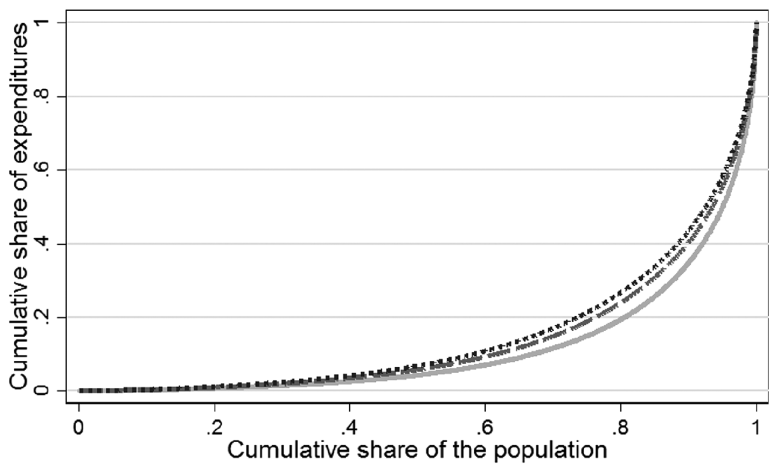

Hospital care

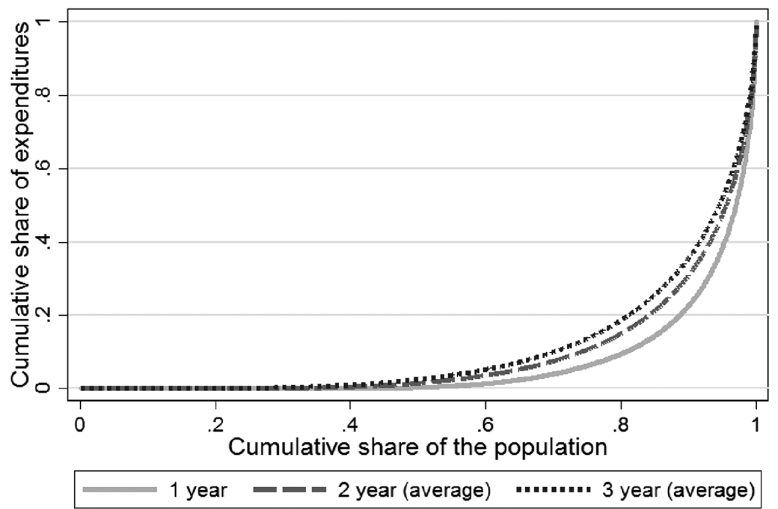

Note: Number of observations is 47,309,246 (one year), 30,859,547 (two years) and 15,107,038 (three years). Personal health care is all medical care and long-term care. Medical care includes hospital care, outpatient medicine and other medical care, including professional services. Hospital care includes inpatient and outpatient care and medicine that is prescribed and administered at the hospital. 
TABLE 10

Measures of the concentration of personal health expenditures over one, two and three years

\begin{tabular}{l|ccc}
\hline & \multicolumn{3}{|c}{ Expenditure averaged over: } \\
& 1 year & 2 years & 3 years \\
\hline Total personal health expenditure & & & \\
Gini coefficient for spending & 0.82 & 0.79 & 0.77 \\
Percentage spent on top 1\% of cases & $24.6 \%$ & $22.7 \%$ & $22.0 \%$ \\
Percentage spent on top 10\% of cases & $74.0 \%$ & $70.4 \%$ & $68.3 \%$ \\
Long-term care expenditure & & & \\
Gini coefficient for spending & 0.98 & 0.98 & 0.98 \\
Percentage spent on top 1\% of cases & $56.4 \%$ & $54.4 \%$ & $53.5 \%$ \\
Percentage spent on top 10\% of cases & $100.0 \%$ & $100.0 \%$ & $100.0 \%$ \\
Medical expenditure & & & \\
Gini coefficient for spending & 0.77 & 0.72 & 0.70 \\
Percentage spent on top 1\% of cases & $23.8 \%$ & $20.1 \%$ & $18.3 \%$ \\
Percentage spent on top 10\% of cases & $65.2 \%$ & $59.6 \%$ & $56.5 \%$ \\
Hospital expenditure & & & \\
Gini coefficient for spending & 0.86 & 0.81 & 0.78 \\
Percentage spent on top 1\% of cases & $29.8 \%$ & $24.0 \%$ & $21.2 \%$ \\
Percentage spent on top 10\% of cases & $77.4 \%$ & $69.1 \%$ & $64.5 \%$ \\
& & & \\
Number of observations & $47,309,246$ & $30,859,547$ & $15,107,038$ \\
\hline
\end{tabular}

Note: Data are expenditures of individuals pooled over 2009-11.

The Lorenz curves for medical expenditures, and particularly hospital expenditures, move inward to a greater extent than that for total health expenditures as the number of years of expenditure is increased. This indicates that these types of expenditure display less persistence than the remaining category, which is expenditure on long-term care. The very high degree of concentration and persistence of long-term care expenditures is evident from the second panel of Table 10. The top 1 per cent of the distribution account for more than half of these expenditures even over a three-year period. Of course, this is due to long-term care being used almost exclusively by the elderly and the steep increase in expenditure on this type of care at the most advanced ages. Over a period substantially longer than three years, the degree of persistence in long-term care expenditures would fall dramatically.

In general, there is a good deal of persistence in all types of health expenditure. Even for hospital expenditures, which one expects to be most acute and least persistent, the Gini coefficient calculated from the three-year averages is only eight hundredths less than that for the single year of data. The 1 per cent of individuals with the highest three-year average hospital expenses account for more than a fifth of spending over the three-year period. 
TABLE 11

Correlation of total personal health expenditure in year $t$ with expenditure in years $t+1$ and $t+2$, by age

\begin{tabular}{l|lc|cc|rr}
\hline & \multicolumn{2}{|c|}{ Spending in levels } & \multicolumn{2}{|c|}{ Spending in logs } & \multicolumn{2}{|c}{ Number of observations } \\
& $t+1$ & $t+2$ & $t+1$ & $t+2$ & $t$ versus $t+1$ & $t$ versus $t+2$ \\
\hline All & 0.66 & 0.56 & 0.67 & 0.61 & $30,859,547$ & $15,128,538$ \\
Aged 0-24 & 0.47 & 0.36 & 0.48 & 0.38 & $8,707,666$ & $4,123,040$ \\
Aged 25-64 & 0.65 & 0.57 & 0.60 & 0.53 & $16,840,457$ & $8,303,905$ \\
Aged 65 and over & 0.68 & 0.57 & 0.73 & 0.66 & $5,311,424$ & $2,701,593$ \\
\hline
\end{tabular}

Note: Correlations between spending in year $t$ and in year $t+1$ are calculated using pairs from the years 200910 and 2010-11; correlations between year $t$ and year $t+2$ are for the years 2009 and 2011. Expenditures below 10 per cent of the mean have been set to that value when calculating log expenditures.

While we find that there is a high degree of persistence in health expenditures over a three-year period, over a longer period there will inevitably be more intertemporal relative to interpersonal variability. Wong et al. (2016) use a non-parametric resampling method to simulate lifetime medical expenditures from Dutch public health insurance claims data for the period 1997-2005. They calculate a Gini index of 0.35 for lifetime expenditures. This is half of the value we estimate for three-year averages for medical expenditures. The distribution of lifetime expenditures is substantially less concentrated than is the cross-sectional distribution. But a Gini of 0.35 is still indicative of a substantial degree of inequality. ${ }^{58}$ Over a lifetime, the medical expenditures of some individuals are substantially greater than those of others.

We can get a partial picture of the contribution of age differences in spending to the persistence of health expenditures over a three-year period by repeating the analysis by age group. In Table 11, we show the serial correlation of total health expenditure for three age groups. Table 12 shows the equivalent of the top panel of Table 10 for each age group. Together, these tables show that health spending is somewhat more persistent among the elderly than among the young and the working-age populations. The correlation between spending in year $t$ and spending in years $t+1$ and $t+2$ is weakest for the youngest group. This suggests, as would be expected, that the degree of chronicity of illnesses and disabilities is higher at older ages. When moving from annual spending to multi-year averages, the shares spent on the top 1 per cent and the top 10 per cent of the distribution, and to some extent the Gini coefficient, decrease less for the population aged 65 and over than they do for the younger age groups. But even at younger ages, there seems to be a good deal of persistence. For both

\footnotetext{
${ }^{58}$ Compare, for example, with a Gini index of 0.25 for equivalised disposable income in a single year in the Netherlands (Eurostat, 2015).
} 
TABLE 12

Measures of the concentration of total personal health expenditure over one, two and three years, by age

\begin{tabular}{l|ccc}
\hline & \multicolumn{3}{|c}{ Total personal health expenditure averaged over: } \\
& 1 year & 2 years & 3 years \\
\hline Aged 0-24 & & & \\
Gini coefficient for spending & 0.77 & 0.72 & 0.70 \\
Percentage spent on top 1\% of cases & $35.9 \%$ & $33.0 \%$ & $31.3 \%$ \\
Percentage spent on top 10\% of cases & $68.9 \%$ & $63.7 \%$ & $61.3 \%$ \\
Number of observations & $13,797,871$ & $8,707,666$ & $4,115,876$ \\
Aged 25-64 & & & \\
Gini coefficient for spending & 0.81 & 0.78 & 0.76 \\
Percentage spent on top 1\% of cases & $29.9 \%$ & $27.9 \%$ & $27.0 \%$ \\
Percentage spent on top 10\% of cases & $72.2 \%$ & $67.6 \%$ & $65.5 \%$ \\
Number of observations & $25,624,847$ & $16,840,457$ & $8,290,358$ \\
Aged 65 and over & & & \\
Gini coefficient for spending & 0.72 & 0.70 & 0.68 \\
Percentage spent on top 1\% of cases & $10.5 \%$ & $9.6 \%$ & $9.6 \%$ \\
Percentage spent on top 10\% of cases & $56.9 \%$ & $54.3 \%$ & $53.5 \%$ \\
Number of observations & $7,886,528$ & $5,311,424$ & $2,700,804$ \\
\hline
\end{tabular}

Note: Data are expenditures of individuals pooled over 2009-11.

of the younger groups, the percentage of total expenditure absorbed by the top 10 per cent falls by only around 7 percentage points in moving from one year to three years of expenditure and the fraction remains above 60 per cent over the three-year period for both.

\section{Conclusion}

In the Netherlands, as in other countries, the greater part of annual health expenditures is concentrated on a relatively small fraction of the population. Moreover, there is a very high degree of persistence in these expenditures, especially among individuals with high expenditures, at least over a three-year period.

Expenditures are concentrated among the old and the dying. This needs to be borne in mind when interpreting the high degree of persistence in expenditures we find over a period of three years. If the horizon of the analysis could be stretched further, then there would be substantially less concentration and persistence. Therefore, one should not rush to conclude that the evidence presented here implies that social health insurance in the Netherlands mainly effects interpersonal redistribution from the rich and healthy to the poor and persistently unhealthy. It also facilitates intrapersonal reallocation from periods 
in good health to periods, and indeed ages, in bad health. But the degree of persistence that we observe over a period of three years does point to a very large proportion of expenditure on conditions that are chronic. It is difficult to insure the risks associated with the onset of such conditions through unregulated private markets and a large part of the welfare gain from social insurance may arise from the provision of such insurance. ${ }^{59}$

About a third of the aggregate health expenditures in the Netherlands are on long-term care. These expenditures are strongly concentrated on the elderly and the dying. Long-term care spending accounts for more than half of all health expenditures incurred in caring for individuals in their last year of life. The comprehensive social long-term care insurance in the Netherlands has led to particularly high expenditures on long-term care. ${ }^{60}$ The Netherlands has a relatively high share of the elderly living in nursing homes ${ }^{61}$ which are the most expensive type of long-term care. High spending on long-term care contributes to a greater concentration of health expenditures on the very old and dying than in other countries and will also contribute to a high concentration on the very high-cost cases. Universal long-term care insurance would also be expected to have implications for wealth accumulation by reducing the need to hold precautionary savings against the risk of care needs in old age. Indeed, many Dutch households hold only a very small amount of liquid assets. $^{62}$

Health expenditures are very strongly negatively correlated with income in the Netherlands. This is not simply an age effect. In part, it is a reflection of the interpersonal redistribution achieved by social health insurance. But one should not forget that health expenditures are made in response to illness, and ill health also impacts on income through the loss of employment. The concentration of health expenditures on those with low incomes can therefore be consistent with the provision of insurance that covers the medical expenses of those losing earnings capacity due to disease and disability.

All in all, it seems that universal and very comprehensive social insurance coverage achieves a great deal of interpersonal and intrapersonal redistribution. The high degree of interpersonal redistribution indicates that, in the Netherlands, the practice is not to 'go Dutch' when paying for health and long-term care. The redistributive effect is strengthened by the high level of health spending - second only to the US in the OECD. It remains to be seen whether this level of spending and redistribution will prove to be sustainable in the coming decades as the share of the elderly in the population rises.

\footnotetext{
${ }^{59}$ Kowalski, 2015.

${ }^{60} \mathrm{OECD}, 2011$.

${ }^{61} \mathrm{OECD}, 2015$.

${ }^{62}$ Van Ooijen, Alessie and Kalwij, 2014.
} 


\section{Supporting information}

Additional supporting information may be found in the online version of this paper on the publisher's website:

- Appendix: Tables A1-A3 and Figure A1

\section{References}

Bakx, P., de Meijer, C., Schut, F. and van Doorslaer, E. (2015), 'Going formal or informal, who cares? The influence of public long-term care insurance', Health Economics, vol. 24, pp. 631-43.

CAK (2015), Bereken uw eigen bijdrage: Zorg met verblijf, http://www.hetcak.nl/portalserver/ portals/cak-portal/pages/k1-1-4-8-bereken-uw-eigen-bijdrage-zorg-met-verblijf.

CBS (2015), Regionale verschillen in gebruik van AWBZ-zorg door ouderen en chronisch zieken in 2012: Onderzoekstoelichting, Centraal Bureau voor de Statistiek, http://www.cbs.nl/NR/ rdonlyres/26F16F77-EF72-459A-BDA4-6F3C77020AFC/0/OnderzoekstoelichtingRegion aleverschilleninAWBZzorg.pdf.

- (2016), StatLine, Centraal Bureau voor de Statistiek, http://statline.cbs.nl.

Citro, C. and Michael, R. (1995), Measuring Poverty: A New Approach, Washington DC: National Academy Press.

de Meijer, C., Koopmanschap, M., Bago d'Uva, T. and van Doorslaer, E. (2011), 'Determinants of long-term care spending: age, time to death or disability?', Journal of Health Economics, vol. 30, pp. 425-38.

-, O'Donnell, O., Koopmanschap, M. and van Doorslaer, E. (2013), 'Health expenditure growth: looking beyond the average through decomposition of the full distribution', Journal of Health Economics, vol. 32, pp. 88-105.

De Nardi, M., French, E., Jones, J. and McCauley, J. (2016), 'Medical spending of the US elderly', Fiscal Studies, vol. 37, pp. 717-47 (this issue).

Eurostat (2015), Database, http://ec.europa.eu/eurostat/data/database.

García-Gómez, P., van Kippersluis, H., O'Donnell, O. and van Doorslaer, E. (2013), 'Long term and spillover effects of health on employment and income', Journal of Human Resources, vol. 48, pp. 873-909.

Helderman, J., Schut, F., van der Grinten, T. and van de Ven, W. (2005), 'Market-oriented health care reforms and policy learning in the Netherlands', Journal of Health Politics, Policy and Law, vol. 30, pp. 189-209.

Hoover, D., Crystal, S., Kumar, R., Sambamoorthi, U. and Cantor, J. (2002), 'Medical expenditures during the last year of life: findings from the 1992-1996 Medicare Current Beneficiary Survey', Health Services Research, vol. 37, pp. 1625-42.

Jonker, J., Sadiraj, K., Woittiez, I., Ras, M. and Morren, M. (2007), Verklaringsmodel Verpleging en Verzorging 2007, The Hague: Netherlands Institute for Social Research (SCP).

Kowalski, A. (2015), 'What do longitudinal data on millions of hospital visits tell us about the value of public health insurance as a safety net for the young and privately insured?', National Bureau of Economic Research (NBER), Working Paper no. 20887.

Mackenbach, J., Slobbe, L., Looman, C., van der Heide, A., Polder, J. and Garssen, J. (2011), 'Sharp upturn of life expectancy in the Netherlands: effect of more health care for the elderly?', European Journal of Epidemiology, vol. 26, pp. 903-14.

NZA (2009), CA-353. Beleidsregel extramurale zorg, http://www.nza.nl/1048076/1048090/ CA_353_Beleidsregel_extramurale_zorg.pdf. 
- (2010), CA-410. Beleidsregel extramurale zorg, http://www.nza.n1/1048076/1048090/CA 410_Extramurale_zorg.pdf.

- (2011), CA-300-469. Prestatiebeschrijvingen en tarieven extramurale zorg, http://www. nza.nl/1048076/1048090/CA_300_469_Prestatiebeschrijvingen_en_tarieven_extramurale zorg.pdf.

OECD (2011), Help Wanted? Providing and Paying for Long-Term Care, Health Policy Study, Paris: Organisation for Economic Cooperation and Development.

- (2015), OECD Health Statistics 2015, http://www.oecd.org/health/health-data.htm.

Oostenbrink, J. and Rutten, F. (2006), 'Cost assessment and price setting of inpatient care in the Netherlands: the DBC case-mix system', Health Care Management Science, vol. 9, pp. 287-94.

Polder, J., Barendregt, J. and van Oers, H. (2006), 'Health care costs in the last year of life: the Dutch experience', Social Science \& Medicine, vol. 63, pp. 1720-31.

Rijksoverheid (2014), Overzicht vergunningen in het kader van de Wet bijzondere medische verrichtingen (Wbmv), http://www.rijksoverheid.nl/documenten-en-publicaties/ vergunningen/2013/02/20/overzicht-vergunningen-in-het-kader-van-de-wet-bijzondere-me dische-verrichtingen-wbmv.html.

- (2016), Eigen risico zorgverzekering, https://www.rijksoverheid.nl/onderwerpen/zorgver zekering/vraag-en-antwoord/eigen-risico-zorgverzekering.

RIVM (2007), Zorg voor euro's 5. Een verkenning van verschillen naar sociaal-economische positie, samenlevingsvorm en land van herkomst, Report no. 270751017, Bilthoven: Rijksinstituut voor Volksgezondheid en Milieu.

- (2013), Zorg voor geest kost nog steeds het meest, Rijksinstituut voor Volksgezondheid en Milieu, http://rivm.n1/Documenten_en_publicaties/Algemeen_Actueel/Nieuwsbericht en/2013/Zorg_voor_geest_kost_nog_steeds_het_meest.

Schut, F. and van de Ven, W. (2011), 'Effects of purchaser competition in the Dutch health system: is the glass half full or half empty?', Health Economics, Policy and Law, vol. 6, pp. 109-23.

- and Varkevisser, M. (2013), 'Tackling hospital waiting times: the impact of past and current policies in the Netherlands', Health Policy, vol. 113, pp. 127-33.

SER (2012), Naar een kwalitatief goede, toegankelijke en betaalbare zorg, Advies 12/06, The Hague: Social and Economic Council of the Netherlands (SER).

Staatscourant (2014), Regeling van de Staatssecretaris van Volksgezondheid, Welzijn en Sport van 18 december 2014, houdende beleidsregels indicatiestelling Wlz 2015, no. 37688, https://zoek.officielebekendmakingen.nl/stcrt-2014-37688.html.

Tsiachristas, A., Dikkers, C., Boland, M. and Rutten-van Mölken, M. (2013), 'Exploring payment schemes used to promote integrated chronic care in Europe', Health Policy, vol. 113, pp. 296-304.

van de Ven, W. and Schut, F. (2008), 'Universal mandatory health insurance in the Netherlands: a model for the United States?', Health Affairs, vol. 27, pp. 771-81.

van Doorslaer, E., Masseria, C. and Koolman, X. for the OECD Health Equity Research Group (2006), 'Inequalities in access to medical care by income in developed countries', Canadian Medical Association Journal, vol. 174, pp. 177-83.

-, Wagstaff, A., van der Burg, H., Christiansen, T., De Graeve, D., Duchesne, I., Gerdtham, U-G., Gerfin, M., Geurts, J., Gross, L., Häkkinen, U., John, J., Klavus, J., Leu, R., Nolan, B., O'Donnell, O., Propper, C., Puffer, F., Schellhorn, M., Sundberg, G. and Winkelhake, O. (2000), 'Equity in the delivery of health care in Europe and the US', Journal of Health Economics, vol. 19, pp. 553-83.

van Kippersluis, H., O’Donnell, O., van Doorslaer, E. and Van Ourti, T. (2010), 'Socioeconomic differences in health over the life cycle in an egalitarian country', Social Science and Medicine, vol. 70, pp. 428-38. 
van Ooijen, R., Alessie, R. and Kalwij, A. (2014), Saving Behavior and Portfolio Choice after Retirement, Panel Paper no. 42, Tilburg: Netspar.

van Winssen, K., van Kleef, R. and van de Ven, W. (2015), 'How profitable is a voluntary deductible in health insurance for the consumer?', Health Policy, vol. 119, pp. 688-95.

Vektis (2011), Zorgthermometer nummer 2: Zorg voor Ouderen, http://www.vektis.nl/ downloads/Publicaties/2011/Zorgthermometer\%20nr2\%202011/.

- (2015), Zorgthermometer nummer 14: Verzekerden in beeld 2015, http://www.vektis. nl/downloads/Publicaties/2015/Zorgthermometer\%20nr14/.

Wong, A., Boshuizen, H., Polder, J. and Ferreira, J. (2016), 'Assessing the inequality of lifetime healthcare expenditures: a nearest neighbour resampling approach', Journal of the Royal Statistical Society: Series A, doi: 10.1111/rssa.12184.

WTZI (2015), Over Toelating Zorginstellingen, https://www.wtzi.nl/overtzi/.

Zorgcijfers (2015a), Financiering van de Zvw en Wlz, http://zorgcijfers.nl/actuele-cijfers/ financiering-van-de-zvw-en-wlz/50.

- (2015b), Premieoverzicht Zvw en Wlz, http://zorgcijfers.nl/actuele-cijfers/premieoverzichtzvw-en-wlz/52.

Zorginstituut Nederland (2015), Over de risicoverevening Zvw, https://www.zorginstituu tnederland.nl/verzekering/risicoverevening+zvw/over+de+risicoverevening+zvw\#ExPos tcompensaties. 